\title{
Kinerja Pembangunan Pertanian dalam Pelaksanaan Penggunaan Anggaran Tugas Pembantuan (TP) di Wilayah Propinsi Kalimantan Selatan
}

\section{Performance of Agricultural Development In the Implementation Budget of Assistance in South Kalimantan Province}

\author{
Bambang Winarso \\ Pusat Sosial Ekonomi dan Kebijakan Pertanian, Bogor
}

\begin{abstract}
South Kalimantan province is one of the potential locations for the development of food crops, especially rice. In line with the government especially the central government has tried in earnest to improve the performance of the agricultural development in the region is mainly to do with efforts to increase the harvested area, production, productivity of both rice crops, corn and soybeans. Aid funding through state funds and deconcentration assistance whose purpose is none other than the effort to reach. Fact shows that there are still any barriers, especially in terms of planning and implementation, especially regarding the budget allocation and the allocation of activities that still have not been synchronized.
\end{abstract}

Keywords: employment dynamics, rural areas and dryland

Diterima: 29-09-2013, disetujui:17-01-2014

\section{PENDAHULUAN}

Sektor pertanian mempunyai peran yang cukup signifikan dalam perekonomian nasional, baik secara langsung maupun tidak langsung. Peran secara langsung antara lain berupa kontribusi dalam pembentukan PDB, penyediaan pangan dan pakan, menghasilkan sumber devisa, penyediaan bahan baku industri, penyediaan lapangan kerja, pengentasan kemiskinan, perbaikan pendapatan masyarakat, dan sumber bioenergi. Sedangkan peran tidak langsung diperoleh dari efek pengganda aktivitas sektor pertanian melalui keterkaitan antara backward and foreward linkage. Berlandaskan pelaksanaan RPJMN ke-2 (2010-2014) ditujukan untuk lebih memantapkan penataan kembali Indonesia di segala bidang dengan menekankan upaya peningkatan kualitas sumber daya manusia termasuk pengembangan kemampuan ilmu pengetahuan dan teknologi serta penguatan daya saing perekonomian. Sasaran utama pembangunan nasional RPJMN 2010-2014 mencakup beberapa hal penting diataranya adalah: (a) kesejahteraan rakyat; (b) perkuatan pembangunan demokrasi; dan (c) penegakan hukum. Lebih lanjut, sasaran pembangunan kesejahteraan rakyat meliputi: ekonomi, pendidikan, kesehatan, pangan, energi, dan infrastruktur.

Sesuai dengan Renstra Kementerian Pertanian 2010-2014, telah ditetapkan 4 (empat) target, yaitu (a) Pencapaian swasembada dan swasembada berkelanjutan; (b) Peningkatan diversifikasi pangan; (c) Peningkatan nilai tambah, daya saing, dan ekspor; (d) Peningkatan kesejahteraan petani. 
Untuk mencapai target tersebut strategi yang ditetapkan dilaksanakan melalui revitalisasi pertanian dengan fokus pada tujuh aspek dasar yang disebut dengan tujuh gema revitalisasi, yang terdiri dari :

(a) Revitalisasi Lahan, antara lain diwujudkan melalui program verifikasi, audit lahan, serta usaha pencetakan sawah dan lahan pertanian baru. (b) Revitalisasi Perbenihan dan Pembibitan, diwujudkan melalui pengembangan riset benih dan bibit, serta program bantuan benih dan bibit. (c) Revitalisasi Infrastruktur dan Sarana, diwujudkan antara lain melalui program perbaikan irigasi desa dan jalan usaha tani serta pengembangan pupuk organik dan rasionalisasi pupuk an organik. (d) Revitalisasi Sumber Daya Manusia, diwujudkan melalui pengembamngan SDM lewat metode Sekolah Lapang, pelatihan dan pemagangan serta pendampingan penyuluh pertanian. (e) Revitalisasi pembiayaan pertanian, diwujudkan melalui program Pengembangan Usaha Agribisnis Pertanian (PUAP), Sarjana Membangun Desa (SMD), Lembaga Distribusi Pangan Masyarakat (LDPM) dan Lembaga Mandiri yang Mengakar di Masayarakat (LM3). (f) Revitalisasi Kelembagaan Petani, diwujudkan melalui berbagai program pemberdayaan Poktan dan Gapoktan serta Lembaga Keuangan Mikro (LKM). (g) Revitalisasi pembiayaan pertanian dan revitalisasi kelembagaan petani, akan menumbuhkan Lembagalembaga Keuangan Mikro (LKM) di pedesaan yang kelak diharapkan akan menjadi cikal bakal terbentuknya Bank Pertanian di desa-desa. (h) Revitalisasi teknologi dan industry hilir, diharapkan bisa menumbuhkan lapangan kerja dan peningkatan pendapatan petani. Sejumlah program dapat dikerahkan untuk mendukung, antara lain lain melalui program pengembangan serta bantuan alat mesin pertanian seperti traktor, pompa air, packing haouse, penggilingan, perontok, dryer, silo, mini feed mill, alat pemerah susu, rumah potong hewan (RPH), serta perangkat pengolahan kompos dan biogas.

Sasaran makro pembangunan pertanian selama tahun 2010 - 2014 mencakup: (a) pertumbuhan PDB pertanian diproyeksikan tumbuh dalam kisaran 3,62 - 3,75 \%; (b) neraca perdagangan pertanian tahun 2010 - 2014 terus meningkat mulai dari US\$ 24,3 milyar di tahun 2010 menjadi US\$ 54,5 milyar di tahun 2014; (c) investasi pertanian PMDN sebesar Rp 45,9 trliyun pada tahun 2010 dan Rp 464,9 trilyun tahun 2014, sementara investasi pertanian PMA sebesar Rp 20,3 trilyun tahun 2010 dan Rp 159,6 trilyun tahun 2014; (d) penyerapan tenaga kerja pertanian tumbuh dalam kisaran 0,89 0,94\% tiap tahun; dan (e) perkembangan Nilai Tukar Petani (NTP) berkisar antara 115 - 120, yang berarti penerimaan petani diharapkan lebih besar dari pengeluaran.

Untuk memperoleh hasil yang maksimal dalam memanfaatkan APBN Kementerian Pertanian Tahun 2011 sebesar Rp. 8,03 trilyun perlu memilih kegiatan prioritas yang benar-benar sebagai pengungkit kegiatan yang lebih besar dan mendorong memanfaatkan modal yang dimiliki masyarakat dan swasta. Guna memperlancar pelaksanaan kegiatan pembangunan pertanian dan sekaligus mengantisipasi permasalahan yang timbul, serta langkah-langkah apa yang dapat dilakukan, yang mungkin timbul pada tahun 2011, maka dilakukan evaluasi pembangunan pertanian.

Tujuan tulisan ini adalah melihat pelaksanaan pembangunan pertanian, mengidentifikasi kendala pelaksanaan kegiatan pembangunan pertanian.

\section{METODE}

Secara metodologis analisis yang digunakan adalah analisis deskriptif berdasarkan data terutama data sekunder yang diambil dari beberapa instansi terkait seperti Biro Pusat Statistik (BPS), dinas/kantor lingkup pertanian provinsi/kab/kota, serta data dari instansi yang terkait lainnya. Data 
Bambang Winarso: Kinerja Pembangunan Pertanian dalam Pelaksanaan Penggunaan Anggaran...

terkait dengan evaluasi pembangunan pertanian mencakup data produksi dan PDRB diolah dengan menggunakan metode Location Quatient ( $L Q)$.

\section{HASIL DAN PEMBAHASAN}

Wilayah Provinsi Kalimantan Selatan secara geografis terletak antara $114^{0} 191^{1} 13^{11}-166^{0} 33^{1}$ $28^{11}$ Bujur Timur dan $1^{0} 21^{1} 49^{11}-4^{0} 10^{1} 14^{11}$ Lintang Selatan, dengan batas-batas sebelah utara berbatasan dengan Provinsi Kalimantan Timur, sebelah timur dengan Selat Makasar, sebelah selatan dengan Laut Jawa dan sebelah barat dengan Provinsi Kalimantan Tengah. Provinsi Kalimantan Selatan mempunyai luas wilayah 37.480.23 $\mathrm{Km}^{2}$ atau kurang lebih 1,9\% dari luas wilayah Republik Indonesia, terdiri dari 147 kecamatan dan 1.968 buah desa. Kabupaten yang paling luas adalah Kotabaru, luas wilayah 9.422,73 $\mathrm{km}^{2}$ atau $25.11 \%$ dari luas Provinsi Kalimantan Selatan, terdiri atas 20 kecamatan dan 195 buah desa. Sedangkan daerah yang terkecil adalah Kota Banjarmasin, yaitu $72,67 \mathrm{~km}^{2}(0,19 \%)$ dengan 5 kecamatan dan 50 buah kelurahan.

Tabel 1 Perkembangan pengunaan lahan di Propinsi Kalimantan Selatan Selama Tahun 2005 2009.

\begin{tabular}{lrrrrr}
\hline \multicolumn{1}{c}{ Jenis penggunaan } & $\mathbf{2 0 0 5}$ & $\mathbf{2 0 0 6}$ & $\mathbf{2 0 0 7}$ & $\mathbf{2 0 0 8}$ & $\mathbf{2 0 0 9}$ \\
\hline Lahan sawah & 597.811 & 633.411 & 623.924 & 472.922 & 669.747 \\
- Irigasi Teknis & 21.174 & 19.887 & 16.187 & 16.052 & 18.861 \\
- Setengah Teknis & 5.661 & 6.157 & 7.564 & 7.654 & 5.871 \\
- Sederhana PU & 11.326 & 11.934 & 11.196 & 11.608 & 13.633 \\
- sederhana Non PU & 18.377 & 23.321 & 19.998 & 15.923 & 23.272 \\
- Tadah Hujan & 178.902 & 177.65 & 180.894 & 159.477 & 189.396 \\
- Pasang Surut & 185.684 & 190.206 & 182.54 & 160.97 & 209.055 \\
- Lebak & 176.687 & 192.293 & 205.545 & 100.687 & 199.789 \\
- Polder dan sawah lainnya & ta & 11.963 & ta & 4.551 & 9.87 \\
Lahan Kering & 258.956 & 376.369 & 362.588 & 421.677 & 424.999 \\
\multicolumn{1}{c}{ - Tegal/kebun } & 258.956 & 270.844 & 262.021 & 268.656 & 275.271 \\
\multicolumn{1}{c}{ - Ladang/huma } & ta & 105.525 & 100.567 & 153.021 & 149.728 \\
\hline TOTAL = & 856.767 & 1.009 .780 & 986.512 & 894.599 & 1.094 .746 \\
\hline
\end{tabular}

Sumber : Dinas Petanian Tanaman Pangan Kalimantan Selatan, 2009

Provinsi Kalimantan Selatan berdasarkan topografi dapat dibagi menjadi 5 (lima) tingkat kemiringan, yaitu :(a). Datar (0-8 \%) Meliputi wilayah sepanjang sungai Barito dan anak sungainya, serta Pantai Timur Kalimantan Selatan. Luas Wilayah sekitar 853.375 ha atau 23,08 \% dari luas wilayah seluruhnya. Wilayah ini sudah terdapat rawa lebak dan pasang surut seluas 700.000 ha. (b) Landai (8-15\%) Meliputi wilayah sebelah dalam dari wilayah diatas, merupakan daerah kering dengan luas sekitar 646.250 ha atau 17,47\% dari luas daratan seluruhnya. (c) Agak Curam (15-25\%) wilayah ini meliputi lereng-lereng bawah sebelah Barat dan Timur Pegunungan Meratus yang memanjang dari tenggara ke Utara dan terletak di tengah-tengah wilayah Propinsi. Luas wilayah ini sekitar 1.751.472 ha atau 47,34 \% dari luas daratan keseluruhannya. Dan (d). Curam (25-45\%)

Merupakan lereng-lereng yang lebih atas disepanjang Pegunungan Meratus dan bagian hulu dari sungai-sungai yang mengalir yang terdapat di Provinsi Kalimantan Selatan. Luas wilayah ini 
sekitar 360.750 ha atau 9,75\% dari luas daratan keseluruhan. Ketinggian tanah di Kalimantan Selatan 80\% kurang dari 100 meter dari permukaan laut, kecuali puncak-puncak pegunungan seperti: Gunung Kakung (1.177 m), Gunung Ambunak (1.150 m), Gunung Haluniah (1.378 m), Gunung Lumut (1.063 $\mathrm{m})$.

Sementara data penggunaan lahan di wilayah Propinsi Kalimantan Selatan selama 5 (lima) tahun terakhir 2005 - 2009 menunjukkan bahwa secara keseluruhan luas lahan sawah diwilayah ini mengalami perkembangan dari 597,81ribu ha pada tahun 2005, meningkat menjadi 669,74 ribu ha pada tahun 2008. Peningkatan luas lahan sawah tersebut di dominasi oleh semakin meluasnya lahan sawah lebak, lahan sawah pasang surut, lahan sawah tadah hujan dan lahan sawah irigasi sederhana. Meningkatnya luas areal pengunaan lahan sawah pada kelas-kelas tersebut disebabkan oleh adalah perbaikan/pengadaan sarana irigasi baru maupun adanya pembukaan lahansawah-lahan sawah baru. Sementara pada periode yang sama (2005 - 2009) perkembangan lahan non sawah/lahan kering juga banyak dialami oleh lahan-lahan tegal/kebun maupun ladang. Perkembangan peningkatan luas penggunaan lahan di Propinsi Kalimantan Selatan tahun 2009 selengkapnya ditampilkan pada Tabel 1.

\section{Struktur Perekonomian}

Struktur perekonomian di Kalimantan Selatan Tahun 2011 berdasarkan data dari BPS, ditunjukkan dari distribusi persentase Produk Domestik Bruto (PDRB) bahwa sektor pertanian menurut lapangan usaha atas dasar harga yang berlaku (tanpa minyak bumi) menyumbang 20,30\% atau Rp.13.69 trilyun dari total PDRB provinsi Rp. 67,48 trilyun. Dari sektor pertanian tersebut khusus untuk Tanaman Bahan Makanan menyumbang sebesar 10,57 \%. Pada tahun 2012 besar PDRB Kalimantan Selatan berdasarkan harga berlaku mengalami peningkatan sebesar 3,6 \% menjadi Rp 14,60 trilyun dan total PDRB (2012) tanpa migas meningkat 5,87 \% menjadi Rp 75,21 trilyun.

PDRB atas dasar harga konstan untuk Tahun 2011 distribusi persentase PDRB untuk sektor pertanian menyumbang sebesar 23,47 \% atau Rp 7,53 trilyun dari total PDRB provinsi Rp 32,10 trilyun (PDRB tanpa migas) dan untuk Tanaman Bahan Makanan menyumbang 11,87\%. Sementara pada tahun 2012 besarnya PDRB tanpa migas meningkat 5,87 \% menjadi Rp 33,98 trilyun dan sumbangan sektor pertabnian terhadap PDRB tersebut sebesar 22,97 \% yaitu sebesar Rp 7,80 trilyun. Dilihat dari besarnya sumbangan secara sektoral, pertanian merupakan sektor utama setelah sektor pertambangan dan penggalian dalam menyumbang pendapatan daerah. Disamping sektor berperan penting dalam menyumbang pendapatan daerah, maka dalam penyerapan tenaga kerja sektor ini memberikan andil yang sangat signifikan sehingga dapat memberikan kemajuan ekonomi bagi wilayah Kalimantan Selatan. Informasi selengkapnya tentang besaran PDRB menurut lapangan usaha/sektor di wilayah Propinsi Kalimantan Selatan Tahun 2009 di tampilkan dalam Tabel 2.

\section{Pelaksanaan Program Pembangunan Tanaman Pangan}

Sektor pertanian merupakan salah satu sektor andalan diwilayah Propinsi Kalimantan Selatan, sektor pertanian mempunyai peran langsung maupun tidak langsung terhadap perekonomian daerah. Salah satu peran penting dalam sektor pertanian adalah penyedian kebutuhan pangan daerah. Sejalan dengan hal tersebut data terakhir menunjukkan bahwa perkembangan luas panen, produksi maupun produktivitas komoditas padi dan palawija khususnya jagung dan kedele. Data pertumbuhan 7(tujuh) tahun terakhir 2005 - 2011 menunjukkan bahwa perkembanagan luas panen padi di wilayah Propinsi Kalimantan Selatan meningkat rata-rata 1,50 \% rata-rata pertahun. Dimana luas panen pada Tahun 2005 seluas 459,54 ribu ha meningkat menjadi 489,13 ribu ha pada Tahun 2011. 
Bambang Winarso: Kinerja Pembangunan Pertanian dalam Pelaksanaan Penggunaan Anggaran...

Tabel 2 : Nilai PDRB Menurut Lapangan Usaha Tahun 2011-2012 dan Pertumbuhan Tahun 2013

\begin{tabular}{|c|c|c|c|c|c|c|c|}
\hline \multirow{2}{*}{ No } & \multirow{2}{*}{ Lapangan Usaha } & \multicolumn{2}{|c|}{ A.d. Harga berlaku } & \multicolumn{2}{|c|}{ A.d. Harga konstan } & \multirow{2}{*}{$\frac{\text { Pertumbuhan }}{(\%)}$} & \multirow{2}{*}{$\begin{array}{l}\text { Sumber } \\
\text { Pertumbhan } \\
\text { Th } 2012\end{array}$} \\
\hline & & 2011 & 2012 & 2011 & 2012 & & \\
\hline 1 & Pertanian & 13696,21 & 14603,48 & 7534,32 & 7805,27 & 3,6 & 0,83 \\
\hline 2 & $\begin{array}{l}\text { Pertambangan dan } \\
\text { penggalian }\end{array}$ & 16659,91 & 18008,90 & 7256,24 & 7447,87 & 2,64 & 0,59 \\
\hline 3 & Industri Pengolahan & 6270,58 & 6865,26 & 3351,18 & 3485,90 & 4,02 & 0,41 \\
\hline 4 & Listrik, gas dan air bersih & 390,93 & 435,47 & 166,34 & 177,87 & 6,93 & 0,04 \\
\hline 5 & Kontruksi & 3994,60 & 4553,77 & 1838,54 & 2019,65 & 9,85 & 0,56 \\
\hline 6 & $\begin{array}{l}\text { Perdagangan, Restoran } \\
\text { dan hotel } \\
\text { Transportasi dan }\end{array}$ & 10447,23 & 12394,97 & 5129,51 & 5631,06 & 9,78 & 1,54 \\
\hline 7 & komunikasi & 5993,78 & 6697,26 & 2872,52 & 3075,25 & 7,06 & 0,62 \\
\hline 8 & $\begin{array}{l}\text { Keuangan, persewaan dan } \\
\text { jasa persh. }\end{array}$ & 3438,30 & 3923,86 & 1342,55 & 1452,93 & 8,22 & 0,34 \\
\hline 9 & Jasa-jasa & 7295,34 & 8440,15 & 3061,39 & 3322,74 & 8,54 & 0,8 \\
\hline 10 & PDRB dengan migas & 68186,88 & 75923,13 & 32552,60 & 34418,54 & 5,73 & 5,73 \\
\hline 11 & PDRB tanpa migas & 67481,90 & 75217,46 & 32101,10 & 33986,94 & 5,87 & 5,87 \\
\hline
\end{tabular}

Sumber : Kalimantan Selatan Dalam Angka 2011-2012

Selama kurun waktu tersebut rata-rata luas panen padi di wilayah Propinsi Kalimantan Selatan adalah 483,57 ribu ha. Meningkatnya areal panen tersebut disamping diasebabkan oleh meningkatnya pembukaan lahan baru, pemanfaatan lahan yang kurang produktif juga disebabkan oleh adanya perbaikan sarana irigasi yang menyebabkan semakin meluasnya lahan sawah yang dapat pengairan. Sementara produksi padi menalami peningkatan rata-rata $4,56 \%$ per tahun dari besarnya produksi padi sebesar 1,59 juta ton pada Tahun 2005 meningkat menjadi 2,03 juta ton pada tahun 2011.

Sementara dalam kurun waktu tersebut (2005-2011) rata-rata produksi padi di wilayah Propinsi Lampung adalah sebesar 1,85 juta ton/tahun. Meningkatnya angka produksi tersebut disamping disebabkan oleh meningkatnya luas panen sebesar rata-rata yang sangat tinggi yaitu sebesar $1,50 \%$ rata-rata per tahun juga disebabkan oleh perkembangan produktivitas padi per hektarnya. Data menunjukkan bahwa selama periode tersebut (2005 - 2011) produktivitas padi di wilayah Propinsi Kalimantan Selatan mengalami peningkatan rata-rata 2,90\% rata-rata pertahun. Dimana produktivitas padi diwilayah Propinsi Lampung pada Tahun 2005 adalah sebesar 34,79 kw/ha dan meningkat menjadi 41,67 kw/ha pada tahun 2011. Meningkatnya angka produktivitas tersebut disamping disebabkan oleh semakin meningkatnya penggunaan sarana produksi sesuai anjuran, juga karena adanya perbaikan sarana-sarana irigasi maupun sarana-sarana lainnya.

Salah satu aplikasi teknologi maju dari tanaman padi di lahan rawa pasang surut Kalsel adalah penerapan teknologi Sawit Dupa (sawit $=$ sekali mewiwit/menyemai, dupa $=$ dua kali panen) yaitu usaha pertanaman padi dengan menggunakan pola tanam bibit unggul - lokal. Teknologi Sawit Dupa merupakan pola tanam alternatif untuk meningkatkan produktivitas usahatani padi di lahan pasang surut. Teknologi ini menyeleraskan antara bertanam padi lokal satu kali panen setahun (pola tanam lama) dengan menyisipkan bertanam padi unggul (pola tanam baru) sehingga diperoleh dua kali panen setahun, yaitu panen padi unggul kemudian panen padi lokal pada lahan yang sama.

Dengan demikian, penerapan teknologi Sawit Dupa akan meningkatkan indeks pertanaman dari $100 \%$ menjadi $180 \%$, karena pada saat pertanaman padi lokasi berada pada tahapan persemaian (lacakan) padi unggul dapat ditanam seluas $80 \%$ dari areal tanam. Dengan demikian penerapkan teknologi sawit dupa akan meningkatkan produktivitas dan membuka peluang bagi peningkatan 
pendapatan petani. Hasil evaluasi pembangunan pertanian yang dilakukan oleh Biro Perencanaan Dept. Pertanian pada tahun 2009 menunjukkan bahwa melalui dana APBD Sawit Dupa seluas 1.000 ha dikembang di 3 (tiga) yaitu Kab. Banjar 350 ha, Batola 350 ha dan Tala 300 ha. Kegiatan dilaksanakan pada 17 kecamatan, tersebar di 20 Desa dan 36 kelompok tani. Sampai dengan bulan Desember 2009 dari rencana seluas 1.000 ha terealisasi $100 \%$.

Informasi diatas setidaknya menunjukkan bahwa dengan adanya peningkatan produksi komoditas tanaman pangan khususnya padi, maka Provinsi Kalimantan Selatan

Dalam hal memenuhi kebutuhan pangan sendiri dapat dikatakan telah mengalami surplus dan menduduki peringkat 9 (sembilan) Nasional. Hasil dari evaluasi biro perencanaan Departemen pertanian menunjukkan bahwa pada tahun 2009 lalu Provinsi Kalimantan Selatan mengalami surplus beras sebesar 623.970 ton, tetapi ini tidak terakumulasi dalam lokasi tertentu namun tersebar ke beberapa tempat.

Seperti diketahui bahwa produksi merupakan salah satu kegiatan di subsistem budidaya yang diarahkan pada peningkatan produktivitas per komoditi tanaman pangan. Komoditas tanaman pangan selain padi terutama jagung dan kedelai di wilayah Propinsi Kalimantan Selatan selama kurun waktu 7(tujuh) tahun terakhir (2005 - 2011) mengalami perkembangan yang bervariasi. Data luas panen jagung selama kurun waktu tersebut menunjukkan peningkatan luas panen yang sangat besar yaitu dengan peningkatan rata-rata 4,24\% pertahun. Luas panen jagung tahun 2005 adalah seluas 15,60 ribu ha meningkat menjadi 19,48 ribu ha pada Tahun 2009 dengan luas panen rata-rata 20,00 ribu ha rata-rata pertahun.

Tabel 3 : Perkembangan luas panen, produksi dan produktivitas untuk komoditas padi, jagung, kedelai di Propinsi Kalimantan Selatan selama lima tahun (2005 - 2011).

\begin{tabular}{|c|c|c|c|c|c|c|c|c|c|}
\hline \multirow[b]{2}{*}{ TAHUN } & \multirow{2}{*}{$\begin{array}{l}\text { Luas } \\
\text { (ha) } \\
\text { panen }\end{array}$} & \multicolumn{2}{|l|}{ Padi } & \multicolumn{3}{|c|}{ Jagung } & \multicolumn{3}{|c|}{ Kedelai } \\
\hline & & $\begin{array}{l}\text { Produksi } \\
\text { (ton) }\end{array}$ & $\begin{array}{l}\text { Produktivitas } \\
\quad \text { (kw/ha) }\end{array}$ & $\begin{array}{l}\text { Luas } \\
\text { (ha) } \\
\text { panen }\end{array}$ & $\begin{array}{l}\text { Produksi } \\
\text { (ton) }\end{array}$ & $\begin{array}{l}\text { Produktivitas } \\
\quad(\mathrm{kw} / \mathrm{ha})\end{array}$ & $\begin{array}{c}\text { Luas } \\
\text { (ha)panen }\end{array}$ & $\begin{array}{l}\text { Produksi } \\
\text { (ton) }\end{array}$ & $\begin{array}{l}\text { Produktivitas } \\
\text { (kw/ha) }\end{array}$ \\
\hline 2005 & 459.541 & 1.598 .835 & 34,79 & 15.604 & 48.103 & 30,83 & 2118 & 2552 & 12,05 \\
\hline 2006 & 462.672 & 1.636 .840 & 35,38 & 17.042 & 58.283 & 34,2 & 1840 & 2138 & 11,62 \\
\hline 2007 & 505.846 & 1.953 .868 & 38,63 & 22.241 & 100.957 & 45,39 & 1806 & 2060 & 11,41 \\
\hline 2008 & 506.580 & 1.954 .284 & 38,52 & 20.116 & 95.064 & 47,26 & 3260 & 3818 & 11,71 \\
\hline 2009 & 490.069 & 1.956 .993 & 39,93 & 22.979 & 113.885 & 49,56 & 3345 & 3838 & 11,47 \\
\hline 2010 & 471.166 & 1.842 .089 & 39,1 & 22.584 & 116.449 & 51,56 & 3154 & 3809 & 12,08 \\
\hline 2011 & 489.134 & 2.038.309 & 41,67 & 19.487 & 99.779 & 51,2 & 3354 & 4376 & 13,85 \\
\hline Rataan & 483.573 & 1.854 .460 & 38,29 & 20.008 & 90.360 & 44,29 & 2697 & 3227 & 12,03 \\
\hline \multicolumn{10}{|c|}{ B. Kenaikan per tahun $(\%)$ : } \\
\hline 2005 & 3,62 & 5,23 & 1,55 & 0,73 & 5,29 & 4,54 & $-51,67$ & $-52,94$ & $-2,67$ \\
\hline 2006 & 0,68 & 2,38 & 1,70 & 9,22 & 21,16 & 10,93 & $-13,13$ & $-16,22$ & $-3,57$ \\
\hline 2007 & 9,33 & 19,37 & 9,19 & 30,51 & 73,22 & 32,72 & $-1,85$ & $-3,65$ & $-1,81$ \\
\hline 2008 & 0,15 & 0,02 & $-0,28$ & $-9,55$ & $-5,84$ & 4,12 & 80,51 & 85,34 & 2,63 \\
\hline 2009 & $-3,26$ & 0,14 & 3,66 & 14,23 & 19,80 & 4,87 & 2,61 & 0,52 & $-2,05$ \\
\hline 2010 & $-3,86$ & $-5,87$ & $-2,08$ & $-1,72$ & 2,25 & 4,04 & $-5,71$ & $-0,76$ & 5,32 \\
\hline 2011 & 3,81 & 10,65 & 6,57 & $-13,71$ & $-14,32$ & $-0,70$ & 6,34 & 14,89 & 14,65 \\
\hline Rataan & 1,50 & 4,56 & 2,90 & 4,24 & 14,51 & 8,64 & 2,44 & 3,88 & 1,79 \\
\hline
\end{tabular}

Sumber : Statistik Indonesia, Badan Pusat Statistik, Statistik Pertanian Tanaman Pangan, 2012 
Bambang Winarso: Kinerja Pembangunan Pertanian dalam Pelaksanaan Penggunaan Anggaran...

Sementara produksi jagung di wilayah Propinsi Kalimantan Selatan pada periode yang sama mengalami peningkatan rata-rata 14,51\% pertahun. Dimana pada tahun 2005 angka produksi tingkat propinsi adalah sebesar 48,10 ribu ton dan meningkat menjadi 99,77 ribu ton pada Tahun 2011. Peningkatan tersebut disebabkan oleh perkembangan areal tanam disamping juga disebabkan oleh semakin meningkatnya produktivitas tanaman. Tingkat produktivitas jagung selama kurun waktu yang sama (2005 - 2011) juga mengalami peningkatan rata-rata $8,64 \%$ dari sebesar 30,83 kw/ha pada tahun 2005 meningkat menjadi 51,10 kw/ha pada Tahun 2011.

Dalam hal pengembangan komoditas kedelai, data menunjukkan bahwa selama kurun waktu yang sama (2005-2011) luas panen kedelai mengalami peningkatan rata-rata 2,44\% pertahun atau rata-rata sekitar 2,69 ribu ha. Dari seluas 2,11 ribu ha pada tahun 2005 meningkat menjadi 3,35 ribu ha pada tahun 2011. Sementara produksi kedelai sampai dengan tahun 2011 mengalami peningkatan ratarata 3,88\% yaitu sebesar 3,22 ribu ton rata-rata pertahun. Artinya mengalami peningkatan dari 2,55 ribu ton pada tahun 2005 menjadi 3,35 ribu ton pada tahun 2011. hal ini dikarenakan adanya peningkatan luas panen sebesar 2,44\%, dari 2,11 ribu ha pada tahun 2005 menjadi 3,35 ribu ha pada tahun 2011. Disamping luas tanam, maka kenaikan produksi kedelai juga dipicu oleh adanya peningkatan produktivitas tanaman. Dimana selama kurun waktu tersebut (2005-2011) produktivitas kedelai meningkat dari $12,05 \mathrm{kw} / \mathrm{ha}$ (2005) meningkat menjadi $13,85 \mathrm{kw} / \mathrm{ha}$ pada tahun 2011.Informasi selengkapnya baik tentang perkembangan luas panen, produksi dan produktivitas dari komoditas padi, jagung dan kedelai ditampilkan dalam tabel 3.

\section{ANALISIS "LQ" untuk komoditas tanaman pangan:}

Pemetaan sentra produksi suatu komoditas terutama komoditas tanaman pangan perlu dilakukan dengan analisis diskriptif analitik, terutama mencakup keragaman pola tanam, teknologi produksi, skala usaha, tingkat produksi dan produktivitas. Pemetaan menggunakan basis data sekunder yaitu luas tanam, areal tanam, produksi dan produktivitas tanaman pangan menurut jenis pada masingmasing wilayah. Dari data tingkat konsentrasi luas tanam, luas areal panen dan produksi akan diketahui pola distribusi luas tanam, luas panen produksi dan produktivitas suatu komoditas tanaman pangan. Pola distribusi menurut waktu terhadap luas tanam, luas panen, produksi dan produktivitas dapat ditampilkan melalui grafik dan sebaran sentra produksi dengan menggunakan peta. Dengan demikian akan diperoleh gambaran kapan saat produksi puncak, sedang dan kurang menurut jenis komoditas tanaman pangan dan waktu.

Salah satu metode yang digunakan untuk menentukan komoditas ungulan dalam suatu wilayah analisis yang digunakan adalah model "Location Quotient" (LQ). Teknik LQ merupakan suatu pendekatan yang umum digunakan dalam model ekonomi basis sebagai langkah awal untuk memahami sektor kegiatan yang menjadi pemacu pertumbuhan. LQ mengukur konsentrasi relatif atau derajat spesialisasi kegiatan ekonomi melalui pendekatan perbandingan. Untuk komoditas yang berbasis lahan seperti tanaman pangan, maka perhitungan didasarkan pada areal panen, produksi atau produktivitas. Dalam hal ini perhitungan didasarkan atas produksi komoditas tanaman pangan pada periode tertentu. Nilai LQ yang diperoleh akan berada dalam kisaran lebih kecil atau sama dengan satu sampai lebih besar daripada satu. Semakin besar LQ suatu wilayah, semakin besar pula derajat konsentrasi diwilayah tersebut. Nilai LQ dihitung pada konsentrasi tingkat nasional dan wilayah propinsi penelitian. Besarnya angka LQ terhadap komoditas tanaman pangan di beberapa wilayah Propinsi-propinsi di Kalimantan berdasarkan angka tara-rata produksi 5 (lima) tahun terakhir disajikan dalam tabel 4. 
Tabel 4 Besarnya angka LQ terhadap komoditas tanaman pangan di beberapa wilayah Propinsipropinsi di Kalimantan berdasarkan angka tara-rata produksi 5 (lima) tahun terakhir.

\begin{tabular}{clcccccc}
\hline \multirow{2}{*}{ o } & \multirow{2}{*}{ PROPINSI } & \multicolumn{3}{c}{ Rata-rata Prod. } & \multicolumn{3}{c}{ LQ } \\
\cline { 3 - 8 } & & Padi & kedelai & jagung & Padi & kedelai & Jagung \\
\hline 1 & Kalimantan Barat & $1.150 .956,8$ & $1.318,6$ & $137.649,6$ & 1,11 & 0,10 & 0,58 \\
2 & Kalimantan Tengah & $529.423,4$ & $1.016,6$ & $3.963,6$ & 1,23 & 0,18 & 0,04 \\
3 & Kalimantan Selatan & $1.737 .188,2$ & $3.113,6$ & $70.808,4$ & 1,19 & 0,17 & 0,21 \\
4 & Kalimantan Timur & 539.397 & $2.425,2$ & $12.938,2$ & 1,21 & 0,42 & 0,13 \\
\hline
\end{tabular}

Hasil analisis LQ terhadap komoditas tanaman pangan (padi, jagung dan kedelai) di wilayah Propinsi Kalimantan Selatan menunjukkan bahwa kisaran LQ untuk komoditas padi rata-rata adalah sebesar 1,67, kedelai adalah 1,22 dan jagung sebesar 1,89. Hal ini berarti secara nasional wilayah propinsi Kalimantan Selatan merupakan wilayah dengan tingkat konsentrasi pengembangan komoditas tanaman pangan yang cukup potensial. Setidaknya dari hasil analisis tersebut ketiga komoditas tanaman pangan yaitu padi, jagung dan kedelai merupakan sumber pertumbuhan dalam kategori sedang untuk beberapa komoditas tanaman pangan tersebut.

Untuk besaran LQ tanaman pangan khususnya padi sebesar 1,67 berarti tingkat konsentrasi produksi padi diwilayah Kalimantan Selatan adalah sebesar 1,67 kali lebih tinggi terhadap konsentrasi produksi padi secara rata-rata nasional. Hal ini sangat wajar mengingat wilayah Kalimantan Selatan merupakan salah satu sentra pertumbuhan padi di P. Kalimantan. Dengan ditemukannya teknologi "Sawit Dupa" hal ini dapat meningkatkan produksi padi melaui IP 180 pertahun. Sedangkan komoditas tanaman pangan lainnya jagung dan kedelai ternyata besaran nilai LQ nya juga $>1$. Informasi selengkapnya tentang hasil analisis LQ terhadap komoditas padi, jagung dan kedelai selama 5(lima) tahun terakhir di wilayah Propinsi Kalimantan Selatan ditampilkan dalam Tabel 3.

\section{Keterpaduan dengan Sumber Pembiayaan Lain}

Mengingat pembangunan pertanian merupakan kegiatan yang berkelanjutan, maka pada kesempatan rapat koordinasi itu juga dibahas tentang: (a) evaluasi pelaksanaan pembangunan pertanian, (b) Simonev, (c) PHLN, (d) SAKIP, (e) SPI dan (f) laporan keuangan menuju WT, (g) perencanaan APBN tahun 2011 dan (h) arahan penggunaan DAK Bidang Pertanian 2011.

Pembangunan Pertanian Tanaman Pangan dan Hortikultura dilaksanakan dalam rangka peningkatan ketahanan pangan, peningkatan daya saing dan peningkatan kesejahteraan petani. Sesuai dengan visi Pembangunan Pertanian Tanaman Pangan dan Hortikultura maka harus dilakukan secara terpadu mendorong dan memberdayakan masyarakat. Kegiatan Evaluasi Pelaksanaan Kegiatan Pembangunan Pertanian yang dilakukan oleh Biro perencanaan Departemen Pertanian meninjukkan bahwa evaluasi kegiatan yangdilaksanakan pada tahun 2009 difokuskan pada Evaluasi Pelaksanaan Dana Tugas Pembantuan Tahun 2009, dan pelaksanaan Pembangunan Pertanian tahun 2010 serta persiapan tahun 2011. Dalam upaya pelaksanaan pembangunan pertanian khususnya Dinas Pertanian Tanaman Pangan dan Hortikultura di wilayah Propinsi Kalimantan Selatan, maka untuk pencapaian sasaran yang ditargetkan telah didukung dana APBN sebesar Rp. 6.972.792.000,- terdiri atas dana Dekonsentrasi Rp. 6.472.792.000,- dan dana Tugas Pembantuan sebesar Rp. 500.000.000,-

Dari laporan evaluasi menunjukkan bahwa :

1.Dana Dekonsentrasi, sejumlah Rp. 6.472.792.000,- berasal dari beberapa sumber 
Bambang Winarso: Kinerja Pembangunan Pertanian dalam Pelaksanaan Penggunaan Anggaran...

diantaranya adalah (a) Direktorat Jenderal Tanaman Pangan Rp. 3,186,192,000,- (b) Direktorat Jenderal Hortikultura Rp. 1,406,600,000,- , (c) Direktorat Jenderal P2HP Rp. 1,080,000,000,- dan (d) Direktorat Jenderal PLA Rp. 800,000,000,-

2.Tugas Pembantuan, sejumlah Rp. 500.000.000,- , yaitu dana yang diperuntukkan membiayai kegiatan Direktorat Pengolahan dan Pemasaran hasil Pertanian/P2HP (Distan TPH Kalsel) Rp.500.000.000,- dan

3.APBD Provinsi sejumlah Rp. 9.202.589.000,- diperuntukkan untuk membiayai beberapa kegiatan diantaranya adalah (a) Program Pelayanan Administrasi Perkantoran Rp. 681.985.000,, (b) Program Peningkatan Sarana dan Prasarana Aparatur Rp. 491.015.000,-, (c) Program Pening.Pengemb.Sistem Pelap. Capaian Kinerja dan Keuangan Rp. 15.000.000,-, (d) Program Peningkatan Kesejahteraan Petani Rp. 200.000.000,-, (e) Program Peningkatan Pemasaran Hasil Produksi Pertanian /Perkebunan Rp. 467.500.000,-, (f) Program Peningkatan Penerapan Teknologi Pertanian /Perkebunan Rp. 1.488.550.000,- dan (g) Program Peningkatan Produksi Pertanian/ Perkebunan sebesar Rp. 5.858.539.000,- Secara rinci anggaran tersebut ditampilkan dalam Tabel 5.

Tabel 5 Alokasi dan realisasi anggaran sumber dana APBN (2009) di Dinas Pertanian Tanaman Pangan dan Hortikultura Provinsi kalimantan Selatan

\begin{tabular}{|c|c|c|c|c|c|}
\hline \multirow{2}{*}{ No } & \multirow{2}{*}{ SATKER } & \multirow{2}{*}{ Pagu } & \multicolumn{3}{|c|}{ Realisasi } \\
\hline & & & Keuangan & $(\%)$ & Fisik $(\%)$ \\
\hline & a. Dana Dekonsentrasi & & & & \\
\hline 1 & Tan. Pangan & 3.186 .192 .000 & 2.512.203.200 & 78,85 & 87,02 \\
\hline 2 & Hortikultura & 1.406 .600 .000 & 1.011 .255 .100 & 71,89 & 83,01 \\
\hline 3 & P2HP & 1.080 .000 .000 & 798.471 .900 & 73,93 & 95 \\
\hline \multirow[t]{3}{*}{4} & PLA & 800.000 .000 & 540.205 .030 & 67,53 & 94 \\
\hline & b. Dana Tugas Perban & & & & \\
\hline & & 6.472 .792 .000 & 4.862 .135 .230 & 75,12 & 89,76 \\
\hline 1 & Dana P2Hp & 500.000 .000 & 460.452 .000 & 92,09 & 100 \\
\hline 2 & $(\mathrm{DK}+\mathrm{TP})$ & 6.972 .792 .000 & 5.322 .587 .230 & 76,33 & 91,81 \\
\hline
\end{tabular}

Sumber : Dinas Tanaman Pangan \& Hortikultura, Kalimantan Selatan, 2009

Pelaksanaannya kegiatan Program Pengembangan Agribisnis untuk Dinas Tanaman Pangan dan Hortikultura di wilayah Propinsi Kalimantan Selatan khususnya alokasi dan realisasi dana Tugas Pembantuan dari satuan kerja (Satker) DirJend P2HP (Pengolahan, Pemasaran Hasil Pertanian) di wilayah Propinsi Kalimantan Selatan Tahun 2009 maka secara keseluruhan realisasi pelaksanaan program tersebut dilihat dari sisi penyerapan dana telah terealisir sebesar 92,09\% dengan realisasi penyelesaian fisik sebesar 100,00\%. Pelaksanaan Program Pengembangan Agribisnis diarahkan pada 3(tiga) kegiatan pokok yaitu (a) Peningkatan kegiatan eksibisi, perlombaan dan penghargaan kepada petani dan pelaku agribisnis, (b) Kegiatan Pengembangan pasca panen pengolahan dan pemasaran hasil tanaman pangan, (c) Revitalisasi LDM.

Informasi menyangkut pagu dana Tugas Pembantuan setiap tahunnya di ketahui pada bulan Januari - Februari. Selain itu dana APBN/Tugas Pembantuan dari pusat diperuntukkan untuk beberapa kegiatan diantaranya adalah (a) pengembangan dan pembinaan tanaman pangan, (b) pengembangan dan pembinaan hortikultura, (c) pengembangan dan pembinaan pengelolaan lahan adan air, (d) pengembangan dan pembinaan pengelolaan pemasaran hasil. Sedangkan kegiatan dari penggunaan 
dana Tugas Pembantuan yang disusun telah diselaraskan dengan kegiatan dana APBD. Untuk kegiatan APBD dan APBN adalah saling melengkapi, kegiatan APBD direncanakan untuk menambah luasan kegiatan yang telah dilaksanakan APBN. Disamping itu kegiatan APBD merupakan awal pengembangan komoditas ungulan yang nantinya diajukan untuk pengembangan di APBN. Sementara itu keberadaan Dana Tugas Pembantuan sudah diintegrasikan dengan dana APBD bentuk sinergismenya diantaranya adalah memfasilitasi dukungan kegiatan yang belum difasilitasi melalui anggaran APBN akan tetapi belum semua pedoman/juknis disampaiakn tepat waktu.

Adapun kendala dan hambatan yang masih harus diatasi diantaranya adalah dalam penyusunan anggaran/program kegiatan sesuai dengan proposal, sementara dalam penyusunan proposal dengan waktu yang sangat terbatas, hal ini mengakibatkan proposal kurang sesuai dengan yang diharapkan. Dalam pelaksanaan kegiatan adanya kendala musim yang tidak menentu yang mengakibatkan pola tanam berubah disamping munculnya ekploitasi hama dan gagal tanam. Sementara dalam kegiatan pemantauan dan evaluasi kegiatan, adanya mutasi petugas monev, menyebabkan petugas yang baru harus belajar dari awal disamping kurangnya sarana prasarana serta kurangnya SDM. Disamping itu dalam hal pelaporan petugas monev sering merangkap banyak satuan kerja, disamping juga sering mengalami mutasi petugas. Dalam penyusunan rancangan program/kegiatan telah mengikuti tahapantahapan perencanaan, akan tetapi hasil akhir masih belum semua yang telah diusulkan diakomodasi oleh pusat. (b) Dalam pelaksanaan kegiatan teknis masih terjadi keterlambatan pembentukan KPA, (c) Dalam pencairan dana baru terlaksana jika KPA telah terbentuk. Dan (d) Dalam kegiatan pemantauan dan monev tidak ada masalah dan dilakukan secara berkesinambungan.

\section{KESIMPULAN}

Dalam perencanaan seyogyanya alokasi kegiatan lebih disesuaiakan dengan kebutuhan propinsi/kabupaten/kota. Disamping itu pusat agar lebih memperhatikan usulan dari daerah yang telah direncanakan melalui tahapan perencanaan yaitu musrenbangtan. Sementara dalam pelaksanaan kegiatan ada beberapa hal yang perlu diperhatikan antara lain : Petunjuk pelaksanaan, juklak diharapkan dapat diterima lebih awal, sehubungan dengan frekwensi mutasi di daerah yang cukup tinggi perlu peraturan yang lebih lanjut mengenai penunjukkan KPA dan PPK. Untuk bisa mendorong sinkronisasi antara kegiatan pusat dan daerah perlu pengaturan lebih lanjut mengenai rumusan kegiatan Kab/Kota yang dibiayai dana daerah dan mengingat rentang kendali yang cukup jauh antara propinsi dan Kab/kota perlu ditinjau ulang penetapan KPA di propinsi dan PPK di Kab/kota. Masalah pencairan dana, semua kabupaten/kota diharapkan dapat mandiri dalam pencairan dana sehingga mempercepat proses pencairan dana di daerah. Disamping itu dalam kegiatan pemantauan dan pelaporan hendaknya selain daerah melaporkan secara berjenjang ke pusat, maka pusat juga melakukan monitoring ke daerah pula agar pusat tahu kondisi sebenarnya dilapangan.

\section{DAFTAR PUSTAKA}

Aninomus. 2009. Rancangan Rencana Strategis kementerian Pertanian Tahun 2010 - 2014 Kementerian Pertanian

Aninomus. 2009. Nota Keuangan dan Anggaran Pendapatan dan Belanja Negara, Tahun 2010. 
Bambang Winarso: Kinerja Pembangunan Pertanian dalam Pelaksanaan Penggunaan Anggaran...

Anonimus. 2012. Statistik Indonesia, Badan Pusat Statistik, Statistik Pertanian Tanaman pangan,

Biro Perencanaan Depatemen Pertanian, 2010. Laporan Hasil Evaluasi Pembangunan Pertanian Pelaksanaan Penggunaan Anggaran Tugas Pembantuan di Provinsi Kalimantan Selatan (tidak dipublikasi).

Dinas Pertanian Tanaman Pangan, Kalimantan Selatan. Penggunaan Lahan di Kalimantan Selatan, 2009.

Dinas Pertanian Tanaman Pangan dan Hortikultura Provinsi Kalimantan Selatan, laporan Tahunan, 2010 